\title{
The serum vaspin levels are reduced in Japanese chronic hemodialysis patients
}

\author{
Junko Inoue', Jun Wada", Sanae Teshigawara', Kazuyuki Hida', Atsuko Nakatsuka', Yuji Takatori', Shoichirou Kojo', \\ Shigeru Akagi ${ }^{1}$, Kazushi Nakao ${ }^{1}$, Nobuyuki Miyatake², John F McDonald ${ }^{3}$ and Hirofumi Makino ${ }^{1}$
}

\begin{abstract}
Background: Visceral adipose tissue-derived serine proteinase inhibitor (vaspin) is an adipokine identified in genetically obese rats that correlates with insulin resistance and obesity in humans. Recently, we found that $7 \%$ of the Japanese population with the minor allele sequence (A) of rs77060950 exhibit higher levels of serum vaspin. We therefore evaluated the serum vaspin levels in Japanese chronic hemodialysis patients.

Methods: Healthy Japanese control volunteers (control; $n=95,49.9 \pm 6.91$ years) and Japanese patients undergoing hemodialysis therapy (HD; $\mathrm{n}=138,51.4 \pm 10.5$ years) were enrolled in this study, and serum samples were subjected to the human vaspin RIA system.

Results: The measurement of the serum vaspin levels demonstrated that a fraction of control subjects $(n=5)$ and HD patients ( $n=11$ ) exhibited much higher levels (> $10 \mathrm{ng} / \mathrm{ml}$; Vaspin High group), while the rest of the population exhibited lower levels ( $<3 \mathrm{ng} / \mathrm{ml}$; Vaspin Low group). By comparing the patients in the Vaspin Low group, the serum vaspin levels were found to be significantly higher in the control subjects $(0.87 \pm 0.24 \mathrm{ng} / \mathrm{ml})$ than in the HD patients $(0.32 \pm 0.15 \mathrm{ng} / \mathrm{ml})(p<0.0001)$. In the stepwise regression analyses, the serum creatinine and triglyceride levels were found to be independently and significantly associated with the vaspin concentrations in all subjects.
\end{abstract}

Conclusions: The creatinine levels are negatively correlated with the serum vaspin levels and were significantly reduced in the Japanese HD patients in the Vaspin Low group.

Keywords: Adipokine, End-stage renal disease, Hemodialysis

\section{Background}

Visceral adipose tissue-derived serine proteinase inhibitor (vaspin) was identified in the visceral adipose tissue of OLETF (Otsuka Long-Evans Tokushima Fatty) rats, which are used in an animal model of obesity and type 2 diabetes [1]. The mRNA expression of vaspin increases at the peak of obesity and insulin resistance in OLETF rats. The injection of recombinant human vaspin into diet-induced obese mice ameliorates insulin resistance and may be a compensatory factor in the status of obesity [2]. In obese adults [3-6] and children [6,7], the serum vaspin levels increase according to the degree of obesity and insulin resistance and decrease in association with weight reduction brought about by life-style

\footnotetext{
* Correspondence: junwada@md.okayama-u.ac.jp

'Department of Medicine and Clinical Science, Okayama University Graduate School of Medicine, Dentistry and Pharmaceutical Sciences, Okayama 700-8558, Japan

Full list of author information is available at the end of the article
}

modifications or bypass surgery. The serum vaspin levels in the patients with type 2 diabetes have been demonstrated to be higher $[8,9]$ or similar to [10] those observed in subjects with normal glucose tolerance. Since short-term continuous subcutaneous insulin infusion decreases the plasma vaspin levels associated with improvements in insulin sensitivity [11], the serum vaspin levels may be influenced by both therapeutic modalities and the status of intrinsic insulin secretion in patients with type 2 diabetes.

Some reports have evaluated the vaspin levels in patients with vascular complications. Low vaspin serum concentrations have been found to be correlated with recently experienced ischemic events in patients with carotid stenosis [12]. The presence of microvascular complications is also associated with low vaspin levels [13]. Among patients receiving chronic dialysis therapy, Seeger et al. reported that the mean serum vaspin 
concentrations are not significantly different between chronic hemodialysis (HD) patients and control subjects, although the vaspin concentrations are positively associated with the serum creatinine levels in HD patients [14]. Recently, we found that $7 \%$ of the Japanese population with the minor allele sequence (A) of rs77060950 exhibit higher levels of serum vaspin (10 ng/ml) [15] and that several SNPs within the vaspin gene are significantly associated with the serum vaspin concentrations, reaching P-values of up to $10^{-35}$ in European populations [16].

Only a small amount of information is available regarding the vaspin levels in HD patients. Serum vaspin levels should be increased in HD patients due to the fact that its small protein size, $50 \mathrm{kDa}$, which would be freely filtered by the kidneys. Furthermore, vaspin seems to increase with increasing insulin resistance and expanding fat mass. Therefore, it was interesting to know whether serum vaspin levels are elevated or reduced in uremic patients undergoing dialysis, who are frequently in the status of malnutrition. We conducted a cross-sectional clinical study to evaluate whether the serum vaspin levels are altered by the renal function and whether the frequency of much higher levels of serum vaspin is different in HD patients. The ELISA system with a measurement range up to $1 \mathrm{ng} / \mathrm{ml}$ (Adipogen) was used in the above mentioned clinical studies. In this study, we employed the RIA system with a wider measurement range from $0.04 \mathrm{ng} / \mathrm{ml}$ to $60 \mathrm{ng} / \mathrm{ml}$ (Millipore, Linco Research). We measured the serum vaspin levels in healthy Japanese control subjects with a normal renal function and HD patients and compared various clinical parameters.

\section{Methods}

\section{Patients}

Healthy Japanese control subjects $(n=95,49.9 \pm 6.91$ years) and patients undergoing hemodialysis therapy $(\mathrm{n}=138$, $51.4 \pm 10.5$ years) were enrolled in this study. The healthy control subjects received annual medical health checkups for common disease screening at the Okayama Southern Institute of Health. The control subjects were without any history of medications for diabetes, hypertension and/or dyslipidemia. The patients were receiving chronic hemodialysis therapy (HD) at Shigei Medical Research Hospital, Okayama, Japan. The exclusion criteria were as follows: malignancies, active infectious diseases, hospitalization during the previous 3 months, and initiation of hemodialysis therapy within 6 months. The patients underwent regular hemodialysis three times a week for 4 to 5 hours per session using polysulfone membranes with a bicarbonate-buffered dialysate. The blood flow was maintained in the range of 150$200 \mathrm{ml} / \mathrm{min}$ with a dialysate flow of $500 \mathrm{ml} / \mathrm{min}$. The study protocol was approved by the ethics committee of Okayama Southern Institute of Health, Okayama University Hospital and Shigei Medical Research Hospital, and written informed consent was obtained from all participants.

\section{Biochemical assays and other measurements}

Body mass index (BMI) was calculated as the weight in kilograms divided by the square of the height in meters. Waist circumference was measured midway between the lower rib margin and the iliac crest. Blood samples were obtained immediately prior to starting a dialysis session. Laboratory data, including the serum levels of creatinine, plasma glucose, total cholesterol, high-density lipoprotein (HDL) cholesterol, triglycerides (TG), albumin and hemoglobin were measured using an automatic analyzer (Hitachi 7150; Hitachi, Tokyo, Japan). Blood pressure (BP) was measured in the supine position before each dialysis session.

The RIA system, which utilizes ${ }^{125}$ I-labeled vaspin as a tracer and a rabbit polyclonal antibody raised against purified rhvaspin, was used to measure the human vaspin levels in sera (Millipore, Linco Research, St. Charles, MO, USA). Hundred $\mu$ l of each standard or each sample was pipetted in duplicate into tubes and mixed with $100 \mu \mathrm{l}$ of human vaspin antibodies. After incubation for $22-24$ hours at $4^{\circ} \mathrm{C}, 100 \mu \mathrm{l}$ of ${ }^{125} \mathrm{I}$-Vaspin tracer was added to all tubes. After incubation for another 2224 hours at $4^{\circ} \mathrm{C}, 10 \mu \mathrm{l}$ of rabbit carrier and $1.0 \mathrm{ml}$ of cold $\left(4^{\circ} \mathrm{C}\right)$ precipitating reagent were added and incubated for 20 minutes at $4^{\circ} \mathrm{C}$. After centrifugation for 20 minutes at $4^{\circ} \mathrm{C}$ at 2000-3000 $\mathrm{x} g$, the supernatant was decanted and the radioactivity of the pellets was counted. Working aliquots of human vaspin standards measuring between $0.01 \mathrm{ng} / \mathrm{ml}$ and $60 \mathrm{ng} / \mathrm{ml}$ were prepared by performing serial 1:2 dilutions of the stock standard of $60 \mathrm{ng} / \mathrm{ml}$. The log values of the standards were plotted versus the sample-bound counts/total binding counts $\left(B / B_{0}\right)$ to construct a standard curve to determine the concentrations of serum vaspin in the unknown samples. The linearity of the standard curve was ascertained to be between $0.26 \mathrm{ng} / \mathrm{ml}$ and $60 \mathrm{ng} / \mathrm{ml}$. The intra- and interassay coefficients of variation $(\mathrm{CV})$ were $5.5 \%$ and $12.3 \%$ at $4.37 \mathrm{ng} / \mathrm{ml}$ and $2.7 \%$ and $12.4 \%$ at $8.44 \mathrm{ng} / \mathrm{ml}$ human vaspin concentrations, respectively. The spike recovery and linearity were in a range of $95.3-101.4 \%$ and $100.0-$ $116.2 \%$, respectively.

\section{Statistical methods}

The descriptive data are presented as the mean \pm SD. The statistical analyses were performed by a Windows personal computer with statistics software JMP 7 (SAS Institute Inc., Cary, NC, USA). $P$-values of $<0.05$ or $<0.01$ were considered to be statistically significant. Differences between two groups were assessed by using the 
Mann-Whitney U test. Correlations between the vaspin levels and clinical characteristics were evaluated with the Spearman's rank correlation test. Stepwise regression analyses based on backward elimination were performed to test the influence of various factors on the vaspin serum concentrations.

\section{Results}

The serum vaspin levels in the control and HD patients

Measurement of the vaspin levels in the human serum samples revealed that the majority of subjects displayed vaspin levels between 0.042 and $1.57 \mathrm{ng} / \mathrm{ml}$. A minor fraction of subjects $(\mathrm{n}=5$ in the control group and $\mathrm{n}=11$ in the HD group) displayed much higher levels, ranging from 16 to $46 \mathrm{ng} / \mathrm{ml}$. Therefore, we classified the participants into two subgroups based on the vaspin serum levels: Vas$\operatorname{pin}_{\text {Low: }}$ vaspin levels $<3 \mathrm{ng} / \mathrm{ml}$ and Vaspin ${ }_{\text {High: }}$ vaspin levels $>10 \mathrm{ng} / \mathrm{ml}$. Henceforth, all of the statistical analyses in the present study were performed among subgroup Vaspin ${ }_{\text {Low }}$, unless otherwise indicated (Table 1). The serum vaspin levels were $0.54 \pm 0.33 \mathrm{ng} / \mathrm{ml}$ (range: $0.042-1.57 \mathrm{ng} / \mathrm{ml}$ ) in the total samples and were significantly higher in the control subjects $(0.87 \pm 0.24 \mathrm{ng} / \mathrm{ml})$ than in the HD patients $(0.32 \pm 0.15 \mathrm{ng} / \mathrm{ml})(\mathrm{p}<0.0001)$. The serum vaspin levels remained lower in the HD patients than in the control subjects following adjustment for the hemoglobin levels $(0.32 \pm 0.15 \mathrm{ng} / \mathrm{ml}$ v.s. $0.92 \pm 0.32 \mathrm{ng} / \mathrm{ml}, \mathrm{p}<0.0001)$ and BMI $(0.32 \pm 0.15 \mathrm{ng} / \mathrm{ml}$ v.s. $0.85 \pm 0.22 \mathrm{ng} / \mathrm{ml}, \mathrm{p}<0.0001)$.

In the HD patients, there were no significant differences in the serum vaspin concentrations between females $(0.35 \pm 0.13 \mathrm{ng} / \mathrm{ml})$ and males $(0.30 \pm 0.16 \mathrm{ng} / \mathrm{ml})$ as well as between diabetic $(0.30 \pm 0.11 \mathrm{ng} / \mathrm{ml})$ and nondiabetic $(0.32 \pm 0.16 \mathrm{ng} / \mathrm{ml})$ patients. Similarly, in the control subjects, the circulating vaspin levels were not significantly different in the gender groups (females: $0.89 \pm 0.21$ vs. males: $0.85 \pm 0.27 \mathrm{ng} / \mathrm{ml}$ ).

\section{Univariate correlations}

In the analysis of the total participants, including the control and HD patients, the serum vaspin levels were found to be statistically correlated with BMI and the levels of plasma glucose, total cholesterol, HDLcholesterol, triglycerides, albumin and hemoglobin. In the control group, the vaspin levels were significantly correlated with the triglyceride levels. However, the serum levels of vaspin did not show any statistical correlations with any of the parameters in the HD patients (Table 2).

\section{Multivariate correlations}

Multiple regression analyses were performed to test whether any of the following factors influence the serum vaspin concentrations: the creatinine and triglyceride levels. When correcting for these variables using stepwise regression analyses, the levels of creatinine and triglycerides were found to be independently and significantly associated with the vaspin concentrations in all subjects (Table 3). The levels of triglycerides significantly predicted the serum vaspin levels in the control group. In the HD patients, no significant correlations were detected between the vaspin levels and any parameter.

Table 1 Baseline characteristics of the healthy controls with lower serum vaspin levels (control/Vaspin Low) $_{\text {) }}$ origher

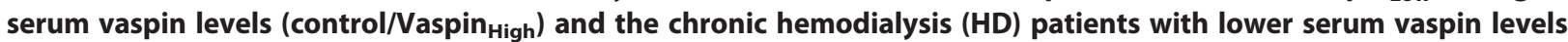
(HD/Vaspin $\left._{\text {Low }}\right)$ or higher serum vaspin levels (HD/Vaspin ${ }_{\text {High }}$ )

\begin{tabular}{|c|c|c|c|c|c|c|}
\hline & Control/Vaspin ${ }_{\text {Low }}$ & HD/Vaspin ${ }_{\text {Low }}$ & $P$ values & Control/Vaspin ${ }_{\text {High }}$ & HD/Vaspin ${ }_{\text {High }}$ & $P$ values \\
\hline Total number & 90 & 127 & & 5 & 11 & \\
\hline Vaspin (ng/ml) & $0.87 \pm 0.24$ & $0.32 \pm 0.15$ & $<0.0001^{*}$ & $23.4 \pm 6.26$ & $31.0 \pm 9.15$ & 0.0785 \\
\hline Gender (female: male) & $48: 42$ & $41: 86$ & $0.0019^{*}$ & $4: 1$ & $5: 6$ & $0.0023^{*}$ \\
\hline Age (years) & $49.7 \pm 6.90$ & $51.9 \pm 10.1$ & 0.0575 & $52.8 \pm 5,47$ & $45.4 \pm 13.7$ & 0.1788 \\
\hline $\mathrm{BMI}\left(\mathrm{kg} / \mathrm{m}^{2}\right)$ & $23.5 \pm 3.84$ & $22.0 \pm 3.46$ & $0.0115^{*}$ & $22.6 \pm 1.62$ & $24.3 \pm 4.79$ & 0.3948 \\
\hline Waist circumference $(\mathrm{cm})$ & $78.1 \pm 11.5$ & $77.8 \pm 9.69$ & 0.8701 & $74.2 \pm 7.32$ & $78.5 \pm 9.91$ & 0.3596 \\
\hline Systolic BP (mmHg) & $124 \pm 16$ & $132 \pm 24$ & $0.0049^{*}$ & $135 \pm 16$ & $128 \pm 27$ & 0.5561 \\
\hline Creatinine (mg/dl) & $0.73 \pm 0.15$ & $13.2 \pm 2.91$ & $<0.0001^{*}$ & $0.74 \pm 0.21$ & $13.0 \pm 3.00$ & $<0.0001^{*}$ \\
\hline Blood glucose $(\mathrm{mg} / \mathrm{dl})$ & $98.6 \pm 28.0$ & $119.2 \pm 43.8$ & $<0.0001^{*}$ & $87.6 \pm 9.48$ & $115.0 \pm 33.0$ & $0.0250^{*}$ \\
\hline Total cholesterol (mg/dl) & $214.4 \pm 36.0$ & $162.2 \pm 40.1$ & $<0.0001^{*}$ & $211.2 \pm 17.0$ & $166.9 \pm 37.8$ & $0.0080^{*}$ \\
\hline HDL cholesterol (mg/dl) & $66.4 \pm 15.1$ & $45.9 \pm 13.9$ & $<0.0001^{*}$ & $65.4 \pm 14.8$ & $52.0 \pm 16.7$ & 0.1467 \\
\hline $\mathrm{TG}(\mathrm{mg} / \mathrm{dl})$ & $135.0 \pm 86.1$ & $127.2 \pm 93.1$ & 0.5397 & $85.2 \pm 24.4$ & $97.2 \pm 27.9$ & 0.4147 \\
\hline Albumin (g/dl) & $4.58 \pm 0.24$ & $3.85 \pm 0.32$ & $<0.0001^{*}$ & $4.56 \pm 0.15$ & $3.65 \pm 0.35$ & $<0.0001^{*}$ \\
\hline Hemoglobin (g/dl) & $14.0 \pm 1.64$ & $10.3 \pm 0.89$ & $<0.0001^{*}$ & $12.4 \pm 2.78$ & $10.1 \pm 0.69$ & 0.1361 \\
\hline
\end{tabular}

The data are presented as the number, ratio or mean \pm s.d. ${ }^{*}, \mathrm{p}<0.05$.

Vaspin Visceral adipose-tissue derived serpin, BMI Body mass index, SFA Subcutaneous fat area, VFA Visceral fat area, BP Blood pressure, HDL High-density lipoprotein, TG Triglycerides. 
Table 2 Univariate analyses of the healthy controls $(n=90)$, chronic dialysis patients $(H D ; n=127)$ and all subjects, including both the healthy controls and chronic dialysis patients $(n=217)$, with lower serum vaspin levels $($ Vaspin Low $)$ using the circulating vaspin levels as dependent variables

\begin{tabular}{|c|c|c|c|c|c|c|}
\hline & \multicolumn{2}{|c|}{ Control/Vaspin ${ }_{\text {Low }}$} & \multicolumn{2}{|c|}{ HD/Vaspin ${ }_{\text {Low }}$} & \multicolumn{2}{|c|}{ All subjects } \\
\hline & $r$ & $P$ values & $r$ & $P$ values & $r$ & $P$ values \\
\hline Age & 0.0331 & 0.7663 & -0.0827 & 0.3556 & -0.1046 & 0.1309 \\
\hline BMI & 0.1184 & 0.2866 & 0.0191 & 0.8638 & 0.2182 & $0.0047^{*}$ \\
\hline Waist circumference & 0.0810 & 0.4667 & 0.0209 & 0.8154 & 0.0563 & 0.4171 \\
\hline Creatinine & -0.0192 & 0.8630 & 0.1526 & 0.0881 & -0.7464 & $<0.0001^{*}$ \\
\hline Blood glucose & 0.1772 & 0.1090 & -0.0218 & 0.8096 & -0.1764 & $0.0108^{*}$ \\
\hline Total cholesterol & 0.1697 & 0.1250 & 0.0987 & 0.2962 & 0.5282 & $<0.0001^{*}$ \\
\hline HDL cholesterol & -0.1901 & 0.0852 & 0.0043 & 0.9634 & 0.4107 & $<0.0001^{*}$ \\
\hline TG & 0.3430 & $0.0015^{*}$ & 0.1212 & 0.1991 & 0.1838 & $0.0097^{*}$ \\
\hline Albumin & -0.0149 & 0.8934 & 0.0741 & 0.4117 & 0.6462 & $<0.0001^{*}$ \\
\hline Hemoglobin & 0.0066 & 0.9526 & 0.0352 & 0.6944 & 0.6784 & $<0.0001^{*}$ \\
\hline
\end{tabular}

${ }^{*}, \mathrm{p}<0.05$. Vaspin Visceral adipose-tissue derived serpin, BMI Body mass index, HDL High-density lipoprotein, TG Triglycerides.

\section{Discussion}

Obesity has undoubtedly influenced the growth of endstage renal disease (ESRD) worldwide [17]; however, some studies have suggested that higher BMIs are associated with improved survival in patients with ESRD $[18,19]$. Adipokines derived from adipose tissues regulate energy homeostasis, insulin sensitivity, lipid metabolism, coagulation, fibrinolysis, inflammation and vascular functions [20]. Therefore, measuring the levels of adipokines in patients with ESRD may be beneficial for predicting cardiovascular events and patient survival. In patients with chronic kidney disease (CKD), the levels of adipokines appear to increase in association with declines in the glomerular filtration rate (GFR). This is most likely due to reduced renal metabolism of adipokines, which may increase vascular risks in patients with a reduced renal function [20]. Among the adipokines, leptin and adiponectin are well-established vasoactive substances, and the serum levels of both leptin and adiponectin have been investigated in patients with ESRD. In patients with incidental coronary heart disease (CHD), the leptin levels exhibit a moderate association with incident CHD [21]. In dialysis patients, poor appetite is associated with fat mass loss and declining leptin levels [22]. Similarly, Scholze et al. demonstrated that low leptin levels predict poor outcomes in dialysis patients, which most likely reflects the detrimental effects of protein energy wasting and loss of fat mass on outcomes in this population [23]. Regarding adiponectin, earlier reports have suggested that higher adiponectin levels are linked to better outcomes

Table 3 Multivariate linear regression analyses of the healthy controls $(n=90)$ and all subjects, including both the healthy controls and chronic hemodialysis patients $(n=217)$, with lower serum vaspin levels $\left(\right.$ Vaspin Low $_{\text {) }}$ using the circulating vaspin levels as dependent variables

\begin{tabular}{|c|c|c|c|c|c|c|c|}
\hline Models & Independent variables & $\beta$ & Standardized $\beta$ & $\beta S E$ & t value & $P$ value & Model $r^{2}$ \\
\hline \multirow[t]{8}{*}{1} & All subjects & & & & & & \\
\hline & Age & -0.003 & 0.002 & -0.070 & -1.247 & 0.214 & 0.586 \\
\hline & BMI & 0.001 & 0.005 & 0.006 & 0.104 & 0.917 & \\
\hline & Hemoglobin & 0.012 & 0.014 & 0.077 & .829 & 0.409 & \\
\hline & $\mathrm{TG}$ & 0.001 & 0.000 & .0154 & 2.643 & $0.009^{*}$ & \\
\hline & Albumin & 0.148 & 0.070 & 0.063 & 0.692 & 0.490 & \\
\hline & Creatinine & -0.030 & 0.005 & -0.620 & -6.511 & $0.000^{*}$ & \\
\hline & Blood glucose & 0.000 & 0.001 & -0.030 & -0.511 & 0.610 & \\
\hline \multirow[t]{4}{*}{2} & Control & & & & & & \\
\hline & Age & -0.001 & 0.004 & -0.035 & -0.311 & 0.757 & 0.119 \\
\hline & BMI & -0.001 & 0.007 & -0.010 & -0.084 & 0.933 & \\
\hline & TG & 0.001 & 0.000 & 0.353 & -3.016 & $0.003^{*}$ & \\
\hline
\end{tabular}

${ }^{*}, \mathrm{p}<0.05$. Vaspin Visceral adipose-tissue derived serpin, BMI Body mass index, TG triglycerides. 
$[24,25]$; however, recent studies show contradictory results $[26,27]$. Drechsler et al. reported that increased longitudinal levels of adiponectin are associated with higher risks of adverse cardiovascular outcomes and death and that this association is weakened by the confounding effects of increased levels of $\mathrm{N}$-terminal prohormone brain natriuretic peptide (NT-pro-BNP)[26]. These studies suggest that the adipokines levels in patients with ESRD are influenced by the renal function, nutritional state and status of inflammation and may affect the vascular function and clinical outcomes.

In the current study, a fraction of the Japanese population, including both healthy subjects and HD patients, exhibited 10-fold higher levels of serum vaspin of more than $10 \mathrm{ng} / \mathrm{ml}$, as demonstrated using the human vaspin RIA system with wider concentration ranges of measurement. Repeated measurement of the serum vaspin levels in this population $\left(\right.$ Vaspin $\left._{\text {High }}\right)$ always demonstrated similarly high levels of vaspin, and one of the subjects' parents also exhibited similar levels. Therefore, such higher vaspin levels are primarily defined by genetic factors. Indeed, we demonstrated that a significant subpopulation (7\%) of both the subjects with normal fasting glucose levels $(n=259)$ and patients with type 2 diabetes $(\mathrm{n}=275)$ displayed much higher levels (10-40 ng/ml; Vaspin $_{\text {High }}$ group), while the serum vaspin levels of $93 \%$ of the samples varied from 0.2 to $3 \mathrm{ng} / \mathrm{ml}$ in the Vaspin $_{\text {Low }}$ group. According to genotyping, rs77060950 is tightly linked to the serum vaspin levels, i.e. CC $(0.6 \pm 0.4 \mathrm{ng} / \mathrm{ml}), \mathrm{CA}(18.4 \pm 9.6 \mathrm{ng} / \mathrm{ml})$ and AA $(30.5$ $\pm 5.1 \mathrm{ng} / \mathrm{ml})\left(\mathrm{p}<2 \times 10^{-16}\right)[15]$. In the current study, we demonstrated that a similar frequency in the Vaspin High $_{\text {}}$ group was observed among the HD patients, who seemed to be genetically defined. Furthermore, the population with vaspin levels higher than $10 \mathrm{ng} / \mathrm{ml}$ included different ethnic groups, i.e. $1 \%$ in European populations, as noted in previous reports [14]. We also demonstrated that $\sim 1 \%$ of the Danish twin population exhibit vaspin levels higher than $10 \mathrm{ng} / \mathrm{ml}$ using the human vaspin RIA system [28]. By separating the patients in the Vaspin ${ }_{\text {High }}$ and Vaspin Low $_{\text {L }}$ groups, we clearly demonstrated that the serum vaspin levels were significantly reduced in the HD patients in the Vaspin $_{\text {Low }}$ group. Seeger et al. did not demonstrate differences in the mean serum vaspin concentrations between chronic hemodialysis (HD) patients and controls, which may be due to the fact that their analysis combined both

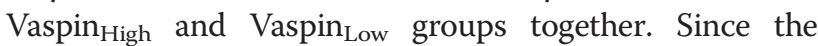
serum vaspin levels correlate with BMI, another explanation for the lower vaspin levels observed in Japanese HD patients may be related to the fact that lower BMI levels are observed in Japanese HD patients than in German HD patients [14].

Lower serum vaspin levels in HD patients are a unique feature, since most adipokines, including leptin, adiponectin and resistin, are higher in ESRD and HD patients. Since the molecular mass of vaspin is $\sim 50 \mathrm{kDa}$ [1], vaspin may not be efficiently eliminated by hemodialysis. The presence of lower serum vaspin levels in HD patients suggest the existence of extra renal elimination of vaspin from the circulation, including the function of clearance receptors on the cell surface of various cells and tissues. Since the serum vaspin levels are wellcorrelated with BMI and the levels of albumin and hemoglobin, vaspin may reflect the nutritional status of HD patients. Recently, the circadian rhythm of the serum vaspin levels has been reported [29]. The serum vaspin levels are highest in the early morning before breakfast and fall to the trough levels within two hours after breakfast. The serum vaspin levels also exhibit preprandial rises and postprandial falls at lunch and dinner, although to lesser degrees than that observed at breakfast [30]. In addition, central and peripheral vaspin administration acutely reduces food intake and exerts sustained blood glucose-lowering effects in mice [30], suggesting the possible role of vaspin in appetite control. The relationship between the reduced vaspin levels observed in HD patients and appetite loss was not determined in the current study, and future studies are required to demonstrate a such link. Since vaspin may exert insulin-sensitizing effects and exhibit antiinflammatory properties in the obesity state $[1,2]$, reduced vaspin levels in $\mathrm{HD}$ patients may be linked to adverse cardiovascular events. The current study is a cross-sectional clinical study and has some limitations. Cohort studies are required to demonstrate whether lower serum vaspin levels are related to poor outcomes in HD patients. To demonstrate such relationships in a cohort study, genetically defined Vaspin ${ }_{\text {High }}$ and Vaspin Low $_{\text {La }}$ groups should be analyzed separately and the Vaspin High $_{\text {}}$ group should be excluded from using vaspin as a marker. Separation of the Vaspin High $_{\text {and Vaspin }}$ Low groups is also important for comparing different ethnic groups, and future studies are required to demonstrate whether the current findings can also be applied to other ethnic populations.

\section{Conclusion}

In summary, measuring the serum vaspin levels demonstrated that $\sim 7 \%$ of both healthy controls and HD patients exhibit much higher levels (> $10 \mathrm{ng} / \mathrm{ml}$; Vaspin ${ }_{\text {High }}$ group), while the rest of the population exhibits lower levels

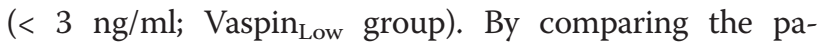

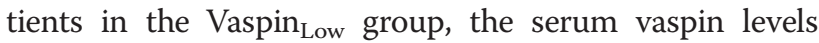
were found to be significantly higher in the control subjects $(0.87 \pm 0.24 \mathrm{ng} / \mathrm{ml})$ than in the HD patients $(0.32 \pm 0.15 \mathrm{ng} / \mathrm{ml})(\mathrm{p}<0.0001)$. In the stepwise regression analyses, the levels of creatinine and triglycerides were found to be independently and significantly associated 
with the vaspin concentrations in all subjects. Future studies are required to determine whether vaspin is a marker of eating behavior and nutrition in HD patients and to demonstrate the importance of the vaspin levels for predicting the outcomes of HD patients.

\section{Competing interests}

The authors declare that they have no competing interests.

\section{Authors' contributions}

$J I, J W, Y T, S K, S A, K N$ and HM participated in the design of the study and recruitment of the patients. JI, ST and JFM established the RIA assay system and obtained all of the measurements. JW, KH and AN participated in the cloning of the vaspin gene and production of recombinant vaspin proteins. JI, JW and HM conceived of the study, participated in coordination and performed the statistical analyses. All authors have read and approved the final manuscript.

\section{Acknowledgements}

This research is supported by a Grant-in-Aid for Scientific Research (B) (23390241), Challenging Exploratory Research (23659470), a Grant-in-Aid for Scientific Research on Innovative Areas "Molecular Basis and Disorders of Control of Appetite and Fat Accumulation (23126516) to J.W., and a Grant-inAid for Scientific Research (A) (21249053) to H.M. from the Ministry of Education, Culture, Sports, Science and Technology of Japan.

\section{Author details}

'Department of Medicine and Clinical Science, Okayama University Graduate School of Medicine, Dentistry and Pharmaceutical Sciences, Okayama 700-8558, Japan. ${ }^{2}$ Department of Hygiene, Faculty of Medicine, Kagawa University, Kagawa 761-0793, Japan. ${ }^{3}$ Millipore, Linco Research, St. Charles, MO 63304, USA.

Received: 18 November 2011 Accepted: 27 November 2012 Published: 3 December 2012

\section{References}

1. Hida K, Wada J, Eguchi J, Zhang H, Baba M, Seida A, Hashimoto I, Okada T, Yasuhara A, Nakatsuka A, et al: Visceral adipose tissue-derived serine protease inhibitor: a unique insulin-sensitizing adipocytokine in obesity. Proc Natl Acad Sci USA 2005, 102(30):10610-10615.

2. Wada J: Vaspin: a novel serpin with insulin-sensitizing effects. Expert Opin Investig Drugs 2008, 17(3):327-333.

3. Chang HM, Lee HJ, Park HS, Kang JH, Kim KS, Song YS, Jang YJ: Effects of weight reduction on serum vaspin concentrations in obese subjects: modification by insulin resistance. Obesity (Silver Spring) 2010, 18(11):2105-2110.

4. Chang HM, Park HS, Park CY, Song YS, Jang YJ: Association between serum vaspin concentrations and visceral adipose tissue in Korean subjects. Metabolism 2010, 59(9):1276-1281.

5. Handisurya A, Riedl M, Vila G, Maier C, Clodi M, Prikoszovich T, Ludvik B, Prager G, Luger A, Kautzky-Willer A: Serum vaspin concentrations in relation to insulin sensitivity following RYGB-induced weight loss. Obes Surg 2010, 20(2):198-203.

6. Suleymanoglu S, Tascilar E, Pirgon O, Tapan S, Meral C, Abaci A: Vaspin and its correlation with insulin sensitivity indices in obese children. Diabetes Res Clin Pract 2009, 84(3):325-328.

7. Lee MK, Jekal Y, Im JA, Kim E, Lee SH, Park JH, Chu SH, Chung KM, Lee HC, Oh EG, et al: Reduced serum vaspin concentrations in obese children following short-term intensive lifestyle modification. Clin Chim Acta 2010, 411(5-6):381-385.

8. El-Mesallamy HO, Kassem DH, El-Demerdash E, Amin Al: Vaspin and visfatin/ Nampt are interesting interrelated adipokines playing a role in the pathogenesis of type 2 diabetes mellitus. Metabolism 2011, 60(1):63-70.

9. Ye Y, Hou XH, Pan XP, Lu JX, Jia WP: Serum vaspin level in relation to postprandial plasma glucose concentration in subjects with diabetes. Chin Med J (Engl) 2009, 122(21):2530-2533.

10. Youn BS, Kloting N, Kratzsch J, Lee N, Park JW, Song ES, Ruschke K, Oberbach A, Fasshauer M, Stumvoll M, et al: Serum vaspin concentrations in human obesity and type 2 diabetes. Diabetes 2008, 57(2):372-377.
11. Li K, Li L, Yang M, Liu H, Liu D, Yang H, Boden G, Yang G: Short-term continuous subcutaneous insulin infusion decreases the plasma vaspin levels in patients with type 2 diabetes mellitus concomitant with improvement in insulin sensitivity. Eur J Endocrinol 2011, 164(6):905-910.

12. Aust G, Richter O, Rohm S, Kerner C, Hauss J, Kloting N, Ruschke K, Kovacs $P$, Youn $\mathrm{BS}$, Bluher M: Vaspin serum concentrations in patients with carotid stenosis. Atherosclerosis 2009, 204(1):262-266.

13. Gulcelik NE, Karakaya J, Gedik A, Usman A, Gurlek A: Serum vaspin levels in type 2 diabetic women in relation to microvascular complications. Eur J Endocrinol 2009, 160(1):65-70.

14. Seeger J, Ziegelmeier M, Bachmann A, Lossner U, Kratzsch J, Bluher M, Stumvoll M, Fasshauer M: Serum levels of the adipokine vaspin in relation to metabolic and renal parameters. J Clin Endocrinol Metab 2008, 93(1):247-251.

15. Teshigawara S, Wada J, Hida K, Nakatsuka A, Eguchi J, Murakami K, Kanzaki $\mathrm{M}$, Inoue $\mathrm{K}$, Terami T, Katayama A, et al: Serum vaspin concentrations are closely related to insulin resistance, and rs77060950 at SERPINA12 genetically defines distinct group with higher serum levels in Japanese population. J Clin Endocrinol Metab 2012, 97(7):E1202-E1207.

16. Breitfeld J, Tonjes A, Bottcher Y, Schleinitz D, Wiele N, Marzi C, Brockhaus C, Rathmann W, Huth C, Grallert H, et al: Genetic variation in the vaspin gene affects circulating serum vaspin concentrations. Int J Obes (Lond) 2012.

17. Hsu CY, McCulloch CE, Iribarren C, Darbinian J, Go AS: Body mass index and risk for end-stage renal disease. Ann Intern Med 2006, 144(1):21-28.

18. Ikizler TA: Resolved: being fat is good for dialysis patients: the Godzilla effect: pro. J Am Soc Nephrol 2008, 19(6):1059-1062.

19. Stenvinkel $P$, Lindholm B: Resolved: being fat is good for dialysis patients: the Godzilla effect: con. J Am Soc Nephrol 2008, 19(6):1062-1064.

20. Carrero JJ, Cordeiro AC, Lindholm B, Stenvinkel P: The emerging pleiotrophic role of adipokines in the uremic phenotype. Curr Opin Nephrol Hypertens 2010, 19(1):37-42.

21. Sattar N, Wannamethee G, Sarwar N, Chernova J, Lawlor DA, Kelly A, Wallace AM, Danesh J, Whincup PH: Leptin and coronary heart disease: prospective study and systematic review. J Am Coll Cardiol 2009, 53(2):167-175.

22. Carrero JJ, Qureshi AR, Axelsson J, Avesani CM, Suliman ME, Kato S, Barany P, Snaedal-Jonsdottir S, Alvestrand A, Heimburger O, et al: Comparison of nutritional and inflammatory markers in dialysis patients with reduced appetite. Am J Clin Nutr 2007, 85(3):695-701.

23. Scholze A, Rattensperger D, Zidek W, Tepel M: Low serum leptin predicts mortality in patients with chronic kidney disease stage 5. Obesity (Silver Spring) 2007, 15(6):1617-1622.

24. Becker B, Kronenberg F, Kielstein JT, Haller H, Morath C, Ritz E, Fliser D: Renal insulin resistance syndrome, adiponectin and cardiovascular events in patients with kidney disease: the mild and moderate kidney disease study. J Am Soc Nephrol 2005, 16(4):1091-1098.

25. Zoccali C, Mallamaci F, Tripepi G, Benedetto FA, Cutrupi S, Parlongo S, Malatino LS, Bonanno G, Seminara G, Rapisarda F, et al: Adiponectin, metabolic risk factors, and cardiovascular events among patients with end-stage renal disease. J Am Soc Nephrol 2002, 13(1):134-141.

26. Drechsler C, Krane V, Winkler K, Dekker FW, Wanner C: Changes in adiponectin and the risk of sudden death, stroke, myocardial infarction, and mortality in hemodialysis patients. Kidney Int 2009, 76(5):567-575.

27. Jorsal A, Tarnow L, Frystyk J, Lajer M, Flyvbjerg A, Parving HH, Vionnet N, Rossing P: Serum adiponectin predicts all-cause mortality and end stage renal disease in patients with type I diabetes and diabetic nephropathy. Kidney Int 2008, 74(5):649-654.

28. Hida K, Poulsen P, Teshigawara S, Nilsson E, Friedrichsen M, Ribel-Madsen R, Grunnet L, Lund SS, Wada J, Vaag A: Impact of circulating vaspin levels on metabolic variables in elderly twins. Diabetologia 2012, 55(2):530-532.

29. Jeong E, Youn BS, Kim DW, Kim EH, Park JW, Namkoong C, Jeong JY, Yoon SY, Park JY, Lee KU, et al: Circadian rhythm of serum vaspin in healthy male volunteers: relation to meals. J Clin Endocrinol Metab 2010, 95(4):1869-1875.

30. Kloting N, Kovacs P, Kern M, Heiker JT, Fasshauer M, Schon MR, Stumvoll M, Beck-Sickinger AG, Bluher M: Central vaspin administration acutely reduces food intake and has sustained blood glucose-lowering effects. Diabetologia 2011, 54(7):1819-1823.

doi:10.1186/1471-2369-13-163

Cite this article as: Inoue et al.: The serum vaspin levels are reduced in Japanese chronic hemodialysis patients. BMC Nephrology 2012 13:163. 